\title{
Questes
}

vestes Revue pluridisciplinaire d'études médiévales

$1 \mid 2002$

Tout un programme

\section{Tout un programme}

Le séminaire

\section{Questes}

\section{OpenEdition}

\section{Journals}

Édition électronique

URL : http://journals.openedition.org/questes/3587

DOI : 10.4000/questes.3587

ISSN : 2109-9472

Éditeur

Les Amis de Questes

\section{Édition imprimée}

Date de publication : 15 novembre 2002

ISSN : 2102-7188

Référence électronique

Questes, «Tout un programme », Questes [En ligne], 1 | 2002, mis en ligne le 01 janvier 2014, consulté le 15 septembre 2020. URL : http://journals.openedition.org/questes/3587

Ce document a été généré automatiquement le 15 septembre 2020.

(C) Association des amis de «Questes » 


\title{
Tout un programme
}

\author{
Le séminaire
}

\section{Questes}

1 Voici le premier bulletin de Questes, bulletin diffusant les recherches du groupe de réflexion « Doctorants médiévistes en Sorbonne ». Réunion de jeunes chercheurs venus d'horizons divers, de France, d'Europe et d'Outre-Atlantique, ce séminaire d'études interdisciplinaire a été créé en 2001, afin de confronter méthodes et expériences et de créer un espace de réflexion commun entre littéraires, linguistes, musicologues, historiens et historiens de l'art médiévistes. Le Moyen Âge est en effet un champ de recherche ouvert à toutes les perspectives, silve où les sentiers, moins battus qu'il n'y paraît, se croisent et s'enchevêtrent pour mener, peut-être, à la senefiance des choses.

2 A l'image de ses participants, aux intérêts variés, Questes n'a pas pour vocation de proposer des réflexions abouties, ni des monuments d'érudition. Le bulletin souhaite refléter, plus simplement, les débats d'idées, les problèmes rencontrés par des étudiants et des enseignants médiévistes. Des réflexions techniques aux expériences aventureuses, por esprover nostre proesce et nostre hardement.

3 Le séminaire des doctorants médiévistes fonctionne sur le principe d'une réunion mensuelle, regroupant les participants qui le souhaitent pour confronter nos idées sur un thème commun, pour apprendre de certains d'entre nous le fonctionnement de champs de recherche moins connus, pour discuter de textes critiques récemment parus. A partir de novembre 2002, les séances suivront un rythme plus soutenu, d'environ toutes les trois semaines, ce qui permettra une participation plus souple. Chaque séance est animée par un ou deux jeunes chercheurs, particulièrement intéressés, pour des raisons personnelles ou professionnelles, par le thème choisi en commun, sous la conduite d'un « médiateur » ou d'un « preud'homme », si vous préférez, esprit éclairé qui aide à la confrontation des points de vue et à l'animation du débat. Le séminaire est aussi l'occasion d'échanger des références bibliographiques ou des annonces sur la tenue de colloques ou de diverses manifestations, en France et à l'étranger.

4 La réunion donne lieu à un compte rendu diffusé auprès de l'ensemble des membres, à un résumé sur la page Web du groupe (actuellement en construction sur le site de la 
Sorbonne), et à la parution des interventions des chercheurs dans Questes, selon une périodicité qui dépendra du bon vouloir de chacun, mais que nous voudrions la plus stable possible.

5 Pour s'inscrire, il suffit d'envoyer vos coordonnées électroniques, votre sujet de thèse et votre directeur, à un des membres du groupe. [...]

INDEX

Mots-clés : Questes 